\title{
Pengaruh kepuasan kerja dan komitmen organisasi terhadap turnover intention
}

\author{
Tya Ananda Rahmah ${ }^{1}$, Sukisno S. Riadi ${ }^{2}$, Syaharuddin $\mathbf{Y}^{3}$ \\ Fakultas Ekonomi dan Bisnis Universitas Mulawarman, Samarinda \\ ${ }^{1}$ Email: tyaananda26@ymail.com \\ ${ }^{2}$ Email: sukisno.rlamet.riadi@feb.unmul.ac.id \\ ${ }^{3}$ Email: syaharuddin.y@feb.unmul.ac.id
}

\begin{abstract}
Abstrak
Penelitian ini dilakukan untuk menguji pengaruh Kepuasan Kerja dan Komitmen Organisasi Terhadap Turnover Intention Pada Karyawan Sales Promotion Girl dan Sales Promotion Boy SOGO Departement Store BIGMALL Samarinda. Sampel penelitian ini terdiri 60 responden. Pengambilan sampel dilakukan dengan menggunakan metode purposive sampling. Teknik analisis data dalam penelitian ini menggunakan analisis regresi linier berganda. Hasil penelitian ini menunjukan bahwa (1) Kepuasan kerja berpengaruh negatif dan signifikan terhadap turnover intention pada karyawan Sales Promotion Girl dan Sales Promotion Boy SOGO Departement Store BIGMALL Samarinda, diperoleh nilai uji t sebesar $-5,346$ dan nilai signifikan kepuasan kerja 0,000<0,05. (2) Komitmen organisasi berpengaruh negatif dan signifikan terhadap turnover intention pada karyawan Sales Promotion Girl dan Sales Promotion Boy SOGO Departement Store BIGMALL Samarinda, diperoleh nilai uji t sebesar -3,125 dan memiliki nilai signifikan komitmen organisasi 0,003 $<0,05$.
\end{abstract}

Kata Kunci: kepuasan kerja; komitmen organisasi; turnover intention

\section{The influence of job satisfaction and organizational commitment to turnover intention}

\begin{abstract}
This Research aim to analyze The Effect of Job Satisfaction and Organizational Commitment on Employee Turnover Intention in Sales Promotion Girl and Sales Promotion Boy SOGO Department Store BIGMALL Samarinda. The research sample consisted of 60 respondents. Election Procedure sample uses purposive sampling method. Data analysis techniques in this study using multiple linear regression analysis. Result of Hypothesis testing (1) Job satisfaction have significant negative effect on employee turnover intention Sales Promotion Girl and Sales Promotion Boy of SOGO Department Store BIGMALL Samarinda, the $t$ test values obtained at $-5,346$ and significant value job satisfaction $0.000<0.05$. (2) Organizational commitment have significant negative effect on employee turnover intention Sales Promotion Girl and Sales Promotion Boy of SOGO Department Store BIGMALL Samarinda, the $t$ test values obtained by $-3,125$ and organizational commitment have significant value $0.003<0.05$.
\end{abstract}

Keywords: job satisfaction; organizational commitment; turnover intention 


\section{PENDAHULUAN}

Keberadaan karyawan merupakan hal yang sangat penting bagi perusahaan karena menjadi salah satu faktor penentu dalam produktifitas perusahaan. Sekarang ini banyak karyawan yang ingin mendapatkan pekerjaan yang layak. Hal ini terlihat dari banyaknya karyawan yang melakukan perpindahan kerja karena mereka menilai apa yang didapat ditempat kerja sekarang tidak sesuai dengan apa yang diharapkan. Kondisi ini mengakibatkan kinerja perusahaan tersebut mengalami kendala akibat adanya karyawan yang melakukan aktivitas berpindah kerja (turnover intention).

Turnover yang terjadi di SOGO Samarinda dalam 1 tahun terakhir sebesar 64\%. Hal ini mengindikasikan tingkat turnover karyawan SOGO Samarinda yang sangat tinggi. Ridlo (2012: 21) menyatakan, proporsi jumlah anggota organisasi yang secara sukarela (voluntary) dan tidak (involuntary) meninggalkan organisasi dalam kurun waktu tertentu umumnya dinyatakan dalam satu tahun, turnover tidak boleh lebih dari $10 \%$.

Setiap karyawan secara individual mempunyai kepuasan kerja yang berbeda, sekalipun berada dalam tipe pekerjaan yang sama hal ini tergantung tingkat kebutuhannya dan sistem yang berlaku pada dirinya. Semakin tinggi kepuasan kerja yang dialami seseorang maka semakin tinggi produktifitas dan kinerja yang akan dihasilkan seseorang karyawan dan mengakibatkan rendahnya keinginan karyawan untuk berpindah kerja atau meninggalkan organisasi.

Komitmen sendiri berkembang tidak lagi sekedar berbentuk kesediaan karyawan menetap di organisasi dalam jangka waktu lama, tetapi lebih dari itu. Karyawan yang memiliki komitmen yang tinggi mau memberikan yang terbaik dan bahkan bersedia untuk bersikap loyal terhadap organisasi yang menyebabkan rendahnya tingkat keinginan untuk berpindah atau meninggalkan organisasi (Turnover Intention).

\section{Kajian Pustaka}

\section{Kepuasan Kerja}

Menurut Robbins and Judge (2008 : 99), kepuasan kerja adalah suatu perasaan positif tentang pekerjaan seseorang yang merupakan hasil dari sebuah evaluasi karakteristiknya. Sedangkan Priansa (2014 : 291), mengatakan bahwa kepuasan kerja merupakan sekumpulan perasaan pegawai terhadap pekerjannya, apakah senang/suka atau tidak senang/tidak suka sebagai hasil interkasi pegawai dengan lingkungan pekerjannya atau sebagai persepsi sikap mental, juga sebagai hasil penilaian pegawai terhadap pekerjannya.

\section{Komitmen Organisasi}

Menurut Robbins and Judge (2008 : 100), menyatakan bahwa komitmen organisasi (organizational commitment) adalah suatu keadaan di mana seorang karyawan memihak organisasi tertentu serta tujuan-tujuan dan keinginannya untuk mempertahankan keanggotaan dalam organisasi tersebut. Mathis and Jackson (2011 : 159), said "Organizational Commitment is the degree to which employees believe in and accept organizational goals and desire to remain with the organization" yang artinya komitmen organisasi adalah sejauh mana karyawan percaya dan menerima tujuan organisasi dan keinginan untuk tetap dengan organisasi.

\section{Turnover Intention}

Menurut Trauth (2008 : 1074), turnover adalah pergerakan tingkat masuk dan keluarnya karyawan dalam perusahaan. Sedangkan turnover intention adalah niat karyawan untuk meninggalkan organisasi. Niat berpindah pekerjaan atau meninggalkan organisasi merupakan keinginan seseorang untuk pindah atau keluar dari perusahaan baik secara sukarela maupun terpaksa. Keinginan ini belum pada tahap realisasi yaitu melakukan perpindahan dari perusahaan tempat bekerja sekarang ke perusahaan lainnya.

\section{Hipotesis Penelitian}

Penelitian yang dilakukan (Utomo: 2015) menunjukan bahwa kepuasan kerja berpengaruh negatif dan signifikan terhadap turnover intention. Artinya karyawan yang memiliki kepuasan kerja 
tidak akan memiliki keinginan untuk meninggalkan perusahaan, sehingga semakin tinggi kepuasan kerja seseorang karyawan maka semakin rendah keinginannya untuk keluar dari perusahaan. Pendapat tersebut juga didukung oleh penelitian (Lim et.,al.: 2013), dan (Sari et.,al: 2015) yang menyatakan adanya hubungan negatif antara kepuasan kerja dengan turnover intention, dimana karyawan yang mencapai kepuasan kerja akan berusaha untuk tetap berada di dalam organisasi.

\section{H1 : Diduga bahwa Kepuasan Kerja berpengaruh negatif dan signifikan terhadap Turnover Intention pada Karyawan Sales Promotion Girl dan Sales Promotion Boy SOGO Departement Store BIGMALL Samarinda.}

Penelitian (Bramantara dan Dewi: 2015) menunjukan bahwa komitmen organisasi berpengaruh negatif dan signifikan terhadap turnover intention. Artinya, semakin tinggi rasa komitmen organisasi yang dimiliki karyawan akan membuat intensitas turnover perusahaan akan menurun. Hal ini sangat berdampak baik bagi perusahaan, karena perusahaan tidak perlu mengeluarkan biaya untuk mencari karyawan baru. Pendapat tersebut juga di dukung oleh penelitian (Abdurrhaman dan Anisah: 2015), (Biantoro dan Sihombing: 2012), dan (Salleh et.,al.: 2012) yang menunjukan komitmen organisasi berpengaruh negatif dan signifikan terhadap turnover intention.

H2 : Diduga bahwa Komitmen Organisasi berpengaruh negatif dan signifikan terhadap Turnover Intention pada Karyawan Sales Promotion Girl dan Sales Promotion Boy SOGO Departement Store BIGMALL Samarinda.

\section{METODE PENELITIAN}

Penelitian ini menggunakan pendekatan kuantitatif yang merupakan metode penelitian yang digunakan untuk meneliti data yang bersifat statistik agar dapat menguji suatu hipotesis. Teknik analisis data menggunakan analisis regresi linier berganda. Populasi dalam penelitian ini sebanyak 337 karyawan Sales Promotion Girl dan Sales Promotion Boy SOGO Departement Store BIG MALL Samarinda yang berlokasi Jalan Untung Suropati No.03 Kecamatan Sungai Kunjang, Kalimantan Timur. Lokasi ini dipilih karena ditemukan masalah masalah yang tekait dengan turnover intention.

Besarnya sampel penelitian sebanyak 60 responden dengan menggunakan rumus Hair et., al. Metode dalam penelitian ini memilih metode purposive sampling. Pengambilan sampel disesuaikan dengan kriteria antara lain: Pria dan Wanita ( $S P B$ dan $S P G)$ yang mencakup minimial kerja 12 bulan atau 1 tahun dan memiliki latar belakang pendidikan minimal SMA/SMK. Syarat tersebut diasumsikan akan memiliki pengaruh terhadap variabel yang diteliti.

Metode pengumpulan data pada penelitian ini yaitu menggunakan teknik penelitian lapangan atau penelitian langsung pada proyek permasalahan dengan mengumpulkan data-data yang diperlukan dengan menggunakan teknik kuesioner, yaitu dengan menggunakan daftar pernyataan yang akan diisi oleh responden dengan skala Likert 1-5. Kuesioner yang disebarkan berupa daftar pernyataan kepada responden mengenai kepuasan kerja, komitmen organisasi dan turnover intention.

\section{HASIL DAN PEMBAHASAN}

Hasil pengujian validitas kuesioner dari semua variabel independen dan variabel dependen memiliki nilai koefisien korelasi lebih besar dari rtabel $>0,214$, sehingga dinyatakan semua variabel penelitian valid. Uji reliabilitas digunakan untuk mengetahui kendalan atau konsistensi instrumen (kuesioner) yang digunakan. Variabel-variabel dalam penelitian ini memiliki nilai Cronbach Alpha lebih besar dari 0,60 (Kepuasan Kerja sebesar 0,620; Komitmen Organisasi sebesar 0,628; dan Turnover Intention sebesar 0,754).

Gambaran umum responden penelitian karyawan Sales Promotion Girl dan Sales Promotion Boy SOGO Departement Store Samarinda bahwa mayoritas presentase responden berusia antara 19 24 Tahun yaitu sebanyak 32 orang (53\%), berjenis kelamin perempuan (SPG) sebanyak 49 orang (82\%), berpendidikan terakhir SMA/SMK sebanyak 46 orang (77\%), lama kerja selama $\geq 1$ Tahun sebanyak 39 orang $(65 \%)$, dan belum menikah sebanyak 33 orang $(55 \%)$. 
Tabel 1. Tanggapan Responden Terhadap Variabel Kepuasan Kerja

\begin{tabular}{clcc}
\hline No & \multicolumn{1}{c}{ Indikator Kepuasan Kerja } & Rata-Rata & Keterangan \\
\hline 1 & Kepuasan Terhadap Pekerjaan itu Sendiri & 4,1 & Baik \\
2 & Kepuasan Terhadap Sikap Atasan & 3,9 & Baik \\
3 & Kepuasan Terhadap Gaji & 3,5 & Baik \\
4 & Kepuasan Terhadap Rekan Kerja & 3,6 & Baik \\
5 & Kepuasan Terhadap Promosi & 3,7 & Baik \\
\hline Rata-Rata Variabel Kepuasan Kerja $\left(\mathrm{X}_{1}\right)$ & 3,8 & Baik \\
\hline
\end{tabular}

Sumber: Data diolah

Berdasarkan tabel 1 di atas, Sales Promotion Girl dan Sales Promotion Boy SOGO Departement Store Samarinda memiliki kepuasan kerja yang baik dari kepuasan terhadap pekerjaan itu sendiri yaitu pekerjaan yang diterima sesuai dengan keinginan karyawan, kepuasan terhadap sikap atasan yaitu adanya hubungan yang baik dengan bawahannya, kepuasan terhadap gaji yaitu gaji yang diterima karyawan sesuai dengan pekerjaanya, kepuasan terhadap rekan kerja yaitu adanya hubungan rekan kerja yang menyenangkan, dan kepuasan terhadap promosi yaitu adanya kesempatan promosi yang lebih jelas.

Tabel 2. Tanggapan Responden Terhadap Variabel Komitmen Organisasi

\begin{tabular}{clcc}
\hline No & \multicolumn{1}{c}{ Indikator Komitmen Organisasi } & Rata-Rata & Keterangan \\
\hline 1 & Komitmen Afektif & 3,5 & Baik \\
2 & Komitmen Berkelanjutan & 3,8 & Baik \\
3 & Komitmen Normatif & 3,5 & Baik \\
\hline & Rata-Rata Variabel Komitmen Organisasi $\left(\mathrm{X}_{2}\right)$ & 3,6 & Baik \\
\hline
\end{tabular}

Sumber: Data diolah

Berdasarkan Tabel 2 di atas, Sales Promotion Girl dan Sales Promotion Boy SOGO Departement Store Samarinda memiliki Komitmen Organisasi yang baik dari komitmen afektif yaitu karyawan merasa perusahaan memiliki arti yang besar, komitmen berkelanjutan yaitu adanya rasa berat meninggalkan organisasi dan komitmen normatif yaitu berpindah dari organisasi satu ke organisasi lain tampak tidak etis bagi karyawan.

Tabel 3. Tanggapan Responden Terhadap Variabel Turnover Intention

\begin{tabular}{clcc}
\hline No & \multicolumn{1}{c}{ Indikator Komitmen Organisasi } & Rata-Rata & Keterangan \\
\hline 1 & Thinking of Quitting & 3,1 & Kurang Baik \\
2 & Intent to Search for Alternatives & 2,8 & Tidak Baik \\
3 & Intent to Quit & 2,3 & Tidak Baik \\
\hline & Rata-Rata Variabel Turnover Intention $(\mathrm{Y})$ & 2,6 & Tidak Baik \\
\hline
\end{tabular}

Sumber: Data diolah

Berdasarkan Tabel 3 di atas, Sales Promotion Girl dan Sales Promotion Boy SOGO Departement Store Samarinda memiliki Turnover Intention yang tidak baik dari Thinking of Quitting yaitu sering berpikiran tentang meninggalkan organisasi, Intent to Search for Alternatives yaitu berkeinginan mencari pekerjaan di perusahaan lain dan Intent to Quit yaitu berkeinginan meninggalkan perusahaan sesegera mungkin.

\section{Koefisien Korelasi dan Determinasi}

Tabel 4. Koefisien Korelasi (R) dan Koefisien Determinasi $\left(\mathrm{R}^{2}\right)$

\section{Model Summary}

\begin{tabular}{|c|c|c|c|c|}
\hline Model & $\mathrm{R}$ & R Square & $\begin{array}{l}\text { Adjusted R } \\
\text { Square }\end{array}$ & $\begin{array}{l}\text { Std. Error of the } \\
\text { Estimate }\end{array}$ \\
\hline 1 &, $686^{\mathrm{a}}$ & ,470 & ,452 &, 494 \\
\hline
\end{tabular}

Sumber: Data diolah dari Output SPSS, 2016

Tabel diatas menunjukan bahwa korelasi $(\mathrm{R})$ antara kedua variabel independen $\left(\mathrm{X}_{1}\right.$ dan $\left.\mathrm{X}_{2}\right)$ terhadap variabel dependennya $(\mathrm{Y})$ adalah 0,686 , ini menunjukkan bahwa $\mathrm{X}_{1}$ (Kepuasan Kerja) dan $\mathrm{X}_{2}$ (Komitmen Organisasi) secara bersama-sama mempunyai hubungan yang kuat terhadap Y (Turnover 
Intention), sehingga perubahan pada kepuasan kerja dan komitmen organisasi yang di alami karyawan akan menyebabkan perubahan pada tingkat turnover intention.

Dari output SPSS nampak bahwa koefisien determinasi atau $R$ Square $\left(R^{2}\right)=0,470$. Hal ini menunjukkan bahwa variasi $\mathrm{Y}$ (turnover intention) dapat dijelaskan oleh $\mathrm{X}_{1}$ (Kepuasan Kerja) dan $\mathrm{X}_{2}$ (Komitmen Organisasi) sebesar 47\% dan selebihnya 53\% dipengaruhi oleh variabel lain yang tidak diteliti dalam penelitian ini. Sedangkan Standard Error of the Estimate (SEE) adalah 0,494 yang menunjukan kesalahan data penelitian. Makin kecil nilai SEE akan membuat model regresi semakin tepat dalam memprediksi variabel dependen.

\section{Analisis Regresi Berganda}

Model analisis regresi linier berganda digunakan untuk mencari koefisien regresi yang akan menentukan apakah hipotesis yang dibuat akan diterima atau ditolak. Dari hasil pengolahan data menggunakan SPSS 22.0 untuk mengetahui Pengaruh Kepuasan Kerja dan Komitmen Organisasi Terhadap Turnover Intention Pada Karyawan Sales Promotion Girl dan Sales Promotion Boy SOGO Departement Store BIG MALL Samarinda, maka dapat dilihat hasil sebagai berikut:

Tabel 5. Coefficients ${ }^{\mathrm{a}}$

\begin{tabular}{llrrrrrr}
\hline & & \multicolumn{2}{c}{$\begin{array}{c}\text { Unstandardized } \\
\text { Coefficients }\end{array}$} & \multicolumn{2}{c}{$\begin{array}{c}\text { Standardized } \\
\text { Coefficients }\end{array}$} & & \\
\cline { 3 - 6 } Model & & B & Std. Error & Beta & & T & Sig. \\
\hline 1 & (Constant) & 7,220 &, 645 & & 11,203 &, 000 \\
& Kepuasan_Kerja &,- 786 &, 147 &,- 534 & $-5,346$ &, 000 \\
& Komitmen_Organisasi &,- 423 &, 135 &,- 312 & $-3,125$ &, 003 \\
\hline Sumber: & Data Diolah dari Output SPSS, 2016 & & & & &
\end{tabular}

Sumber: Data Diolah dari Output SPSS, 2016

Berdasarkan tabel di atas, maka dapat disusun persamaan regresi linier berganda sebagai berikut: $\mathrm{Y}=\mathbf{7 , 2 2 0}-\mathbf{0 , 7 8 6} \mathrm{X}_{\mathbf{1}}-\mathbf{0 , 4 2 3} \mathrm{X}_{\mathbf{2}}$

1) Konstanta sebesar 7,220; artinya jika kepuasan kerja $\left(X_{1}\right)$ dan komitmen organisasi $\left(X_{2}\right)$ nilainya 0 , maka Turnover Intention (Y) yang terjadi sebesar 7,220.

2) $X_{1}=-0,786$; menunjukkan bahwa variabel kepuasan kerja $\left(X_{1}\right)$ berpengaruh negatif terhadap turnover intention $(\mathrm{Y})$, yang artinya apabila terjadi peningkatan pada variabel kepuasan kerja $\left(\mathrm{X}_{1}\right)$ maka tingkat turnover intention $(\mathrm{Y})$ menurun, begitu juga sebaliknya.

3) $\mathrm{X}_{2}=-0,423$, menunjukkan bahwa variabel komitmen organisasi $\left(\mathrm{X}_{2}\right)$ berpengaruh negatif terhadap turnover intention $(\mathrm{Y})$, yang artinya apabila terjadi peningkatan pada variabel komitmen organisasi $\left(\mathrm{X}_{2}\right)$ maka tingkat turnover intention $(\mathrm{Y})$ menurun, begitu juga sebaliknya.

Dari hasil pengujian hipotesis dengan uji $t$ atau uji secara parsial yang dimaksudkan untuk mengetahui pengaruh dari masing-masing atau individu variabel independen yaitu kepuasan kerja $\left(\mathrm{X}_{1}\right)$ dan komitmen organisasi $\left(\mathrm{X}_{2}\right)$ terhadap variabel dependen turnover intention $(\mathrm{Y})$ sebagai berikut:

\section{a. Pengaruh Kepuasan Kerja Terhadap Turnover Intention}

Berdasarkan tabel diatas kepuasan kerja memiliki nilai koefisien beta $-0,786$. Hasil uji parsial atau uji $t$ diperoleh nilai $t_{\text {hitung }}$ lebih besar dari $t_{\text {tabel }}$ yaitu (-) 5,346 > 1,671 dengan tingkat signifikansi sebesar $0,000<0,05$, sehingga dapat dinyatakan kepuasan kerja berpengaruh negatif dan signifikan terhadap turnover intention pada karyawan Sales Promotion Girl dan Sales Promotion Boy SOGO Departement Store Samarinda, yang artinya jika kepuasan kerja meningkat maka akan menurunkan tingkat turnover intention, begitu juga sebaliknya jika kepuasan kerja menurun maka akan meningkatkan turnover intention. Sehingga Hipotesis yang menyatakan bahwa kepuasan kerja berpengaruh negatif dan signifikan terhadap turnover intention diterima atau $\mathrm{H}_{1}$ diterima.

Hasil penelitian ini sejalan dengan penelitian yang dilakukan (Widyantara dan Ardana: 2015), (Lim et.,al.: 2013) dan (Sari et.,al.: 2015), dalam penelitiannya menyimpulkan kepuasan kerja mempunyai pengaruh negatif dan signifikan terhadap turnover intention dimana jika tingkat kepuasan kerja karyawan rendah maka keinginan berpindah atau turnover intention meningkat. Kepuasan kerja seorang karyawan harus dijaga dengan baik oleh perusahaan karena karyawan merupakan aset 
terpenting sebuah perusahaan untuk menjalankan operasionalnya. Dengan adanya kepuasan kerja yang tinggi membuat karyawan menjadi terfokus pada usaha untuk mencapai hasil kerja yang baik sesuai dengan tujuan perusahaan, sehingga menurunkan tingkat turnover intention.

\section{b. Pengaruh Komitmen Organisasi Terhadap Turnover Intention}

Berdasarkan tabel diatas komitmen organisasi memiliki nilai koefisien beta $-0,423$. Hasil uji parsial atau uji $t$ diperoleh nilai $t_{\text {hitung }}$ lebih besar dari $t_{\text {tabel }}$ yaitu (-) 3,125>1,671 dengan tingkat signifikansi sebesar $0,003<0,05$, sehingga dapat dinyatakan komitmen organisasi berpengaruh negatif dan signifikan terhadap turnover intention pada karyawan Sales Promotion Girl dan Sales Promotion Boy SOGO Departement Store Samarinda, yang artinya jika komitmen organisasi meningkat maka akan menurunkan tingkat turnover intention, begitu juga sebaliknya jika komitmen organisasi menurun maka akan meningkatkan tingkat turnover intention. Sehingga Hipotesis yang menyatakan bahwa komitmen organisasi berpengaruh negatif dan signifikan terhadap turnover intention diterima atau $\mathrm{H}_{2}$ diterima.

Hasil penelitian ini sejalan dengan penelitian sebelumnya yang dilakukan (Sutanto dan Gunawan: 2013), (Bramantara dan Dewi: 2015), dan (Salleh et.,al.: 2012) dalam penelitiannya menyimpulkan bahwa komitmen organisasi berpengaruh negatif dan signifikan terhadap turnover intention. Jika komitmen organisasi menurun maka akan meningkatkan keinginan berpindah (turnover intention). Perusahaan yang memiliki rasa komitmen organisasi yang baik maka akan membuat dampak baik bagi perusahaan, karena seorang karyawan yang memiliki komitmen organisasi yang tinggi cenderung berkerja secara maksimal terhadap organisasi sehingga meningkatkan produktivitas kerja dan tercapainya tujuan perusahaan.

\section{SIMPULAN}

Berdasarkan hasil analisis penelitian dan hasil pembahasan di atas, maka dapat di tarik kesimpulan yaitu sebagai berikut:

1) Variabel kepuasan kerja $\left(\mathrm{X}_{1}\right)$ berpengaruh negatif dan signifikan terhadap turnover intention $(\mathrm{Y})$ pada karyawan Sales Promotion Girl dan Sales Promotion Boy SOGO Departement Store Samarinda. Hal ini berarti kepuasan kerja memiliki pengaruh negatif terhadap turnover intention, yang artinya jika kepuasan kerja karyawan meningkat maka tingkat turnover intention menurun. Sebaliknya, jika kepuasan kerja karyawan menurun maka tingkat turnover intention meningkat.

2) Variabel komitmen organisasi $\left(\mathrm{X}_{2}\right)$ berpengaruh negatif dan signifikan terhadap turnover intention (Y) pada karyawan Sales Promotion Girl dan Sales Promotion Boy SOGO Departement Store Samarinda. Hal ini berarti komitmen organisasi memiliki pengaruh negatif terhadap turnover intention, yang artinya apabila komitmen organisasi karyawan meningkat maka tingkat turnover intention menurun. Sebaliknya, jika komitmen organisasi yang karyawan menurun maka tingkat turnover intention meningkat.

\section{DAFTAR PUSTAKA}

Armstrong, Michael and Duncan Brown. 2006. Strategic Reward Making it Happen, United States.

Abdurrahim, dan Hastin Umi Anisah. 2015. Pengaruh Kepuasan Kerja dan Komitmen Organisasi Terhadap Turnover Intention karyawan (Studi pada PT. Bank Perkereditan Rakyat Mitratama Arthabuana).

Afandi, Pandi. 2016. Concept and Indicator Human Resources Management For Management Research. Deepublish: Yogyakarta.

Bangun, Wilson. 2012. Manajemen Sumber Daya Manusia, Penerbit Erlangga.

Biantoro, Linda dan Ranto P. Sihombing. 2012. Pengaruh Komitmen Organisasi Terhadap Turnover Intention Melalui Kepuasan Kerja dengan Budaya Organisasi sebagai Variabel Anteseden. Jurnal Akuntansi Bisnis, Vol.XI No.21.

Bramantara, Gusti NB, dan AA. Sagung K. Dewi. 2015 Pengaruh Kepuasan Kerja dan Komitmen Organisasi Terhadap Turnover Intention Karyawan pada Krisna Oleh-Oleh Khas Bali III. 
Foon, Yeoh Sok., Lim Chee-Leong, and Syuhaily Osman. 2010. An Exploratory Study on Turnover Intention among Private Sector Employees, International Journal of Business and Management. Vol. 5.

Jansen, Paul G.W. and Gert Roodt. 2015. Conceptualising and Measuring Work Identity, Springer Science.

Jex, Steve M. and Thomas W. Britt. 2014. Organizational Psychology a Scientist- Practitioner Approach. Third Edition. United States of America.

Lim, Sheila Omar., Tnay, Otman and Siong. 2013. The influences of job satisfaction and organizational commitment on turnover intention. Social and Behavioral Sciences 97, $201-$ 208. ELSEVIER.

Mathis, Robert L. and Jackson John H. 2011. Human Resource Management. South-Western, Cengage Learning.

Novliadi, F. 2010. Intensi Turnover Karyawan ditinjau dari Budaya Perusahaan dan Kepuasaan Kerja, Universitas Sumatra Utara, Medan.

Priansa, Donni Juni. 2014. Perencanaan dan Pengembangan Sumber Daya Manusia, Penerbit: Alfabeta Bandung.

Ridlo, Ilham Akhsanu. 2012. Turnover Karyawan "Kajian Literatur”, Surabaya: PH Movement Publication.

Robbins, Stephen P. and Timothy A. Judge. 2008. Organizational Behaviour. Angelica et.,al (terjemahan). Perilaku Organisasi, Edisi Duabelas, Penerbit Salemba Empat: Jakarta.

Salleh, Mishaliny S.N. and Haryani H. 2012. Job Satisfaction, Organizational Commitment and Turnover Intention : A care Study on Employees of Retail Company in Malaysia. World Academy of Science, Enginering and Tecnology, pp : 316-322.

Sari, Nita Ratna, M. Soe'oed Hakam, dan Heru Susilo. 2015. Pengaruh Kepuasan Kerja Terhadap Turnover Intention (Studi pada AJB Bumiputera 1912 Kantor Wilayah Jatim II/ Malang). Fakultas Ilmu Administrasi. Universitas Brawijaya.

Sopiah. 2008. Perilaku Organisasi, Yogyakarta: Andi Offset.

Sugiyono. 2014. Metode Penelitian Kuantitatif, Kualitatif, dan Kombinasi (Mixed Methods), Alfabeta: Bandung.

Sutanto, Eddy M. dan Carin Gunawan. 2013. Kepuasan Kerja, Komitmen Organisasional dan Turnover Intentions. Universitas Kristen Petra, Surabaya. Jurnal Mitra Ekonomi dan Manajemen Bisnis, Vol.4, No.1, 76-78.

Trauth, Eileen M. 2008. Encyclopedia of Gender and Information Technology, Idea Group Reference. United States.

Utomo, Vista Pitaloka. 2015. Analisis Pengaruh Kepuasan Kerja dan Komitmen Organisasi terhadap Turnover Intention pada Karyawan Swalayan Ramai Ungaran. Univ. Dian Nuswantoro.

Widyantara, Ida Bagus dan I Komang Ardana. 2015. Pengaruh Kepuasan Kerja dan Komitmen Organisasi Terhadap Intensitas Turnover Karyawan. E-Jurnal Manajemen Unud, Vol. 4, No. 6, 2015: 1670-1683. 